\title{
Changes of Estrogens in Milk of Thoroughbred Mares During Foal Estrus
}

\author{
Toshitada Higashino, Keisuke Shimizu, Shigehisa Tsumagari, \\ and Masatoshi TAKeIsHI \\ Department of Veterinary Obstetrics and Gynecology, College of Agriculture \\ and Veterinary Medicine, Nihon University, Fujisawa, 252, Japan
}

(Accepted for publication April 7, 1989)

\begin{abstract}
Summary. Levels of three kinds of estrogens, estrone, estradiol-17 $\beta$ and estriol, in milk from 5 Thoroughbred mares during foal estrus were measured by radioimmunoassay. Estradiol-17 $\beta$ and estriol levels in milk have no relevant importance in predicting conceptionable estrus. Only estrone concentration in milk showed a relation to the conceptionable estrus cycle in thoroughbred mares. This is probably the first report that deals with estrone concentration in milk during foal estrus and the measurement of estrone could be a reliable guide to know the estrus to be capable of conception in postpartum mares.
\end{abstract}

KEY WORDS: MARE, MILK, ESTROGEN, FOAL ESTRUS.

Jpn J Anim Reprod 35, 92-96, 1989

Plasma levels of estradiol in mares of different breeds have been measured near estrus (Norden et al., 1976) and before ovulation (Pattison et al., 1974). Further, progesterone concentration in milk and blood plasma from Quarter Horse mare during foal estrus have been determined (Gunter et al., 1980).

However, no papers have been published on estrogen concentration changes in milk of Thoroughbred mares. Therefore the objectives of this study were to compare daily changes in concentrations in three kinds of estrogens, estrone (E1), estradiol-17 $\beta$ (E2) and estriol (E3), in milk from Thoroughbred mares during foal estrus, and to determine the relationships between the levels of estrogens and conceptional ability in that estrus.

\section{Materials and Methods}

Milk samples were obtained daily from 5 lactating Thoroughbred mares by manual milking from the onset of foal estrus to 30 days afterward. Mares were checked daily for estrus with a stallion during estrus. Ovaries were examined by rectal palpation in estrus mare to detect the estimated time of ovulation. Pregnancy was also detected by rectal palpation of cervix, uterus and ovaries. Milk collected was immediately centrifuged $3000 \mathrm{rpm}$ for $10 \mathrm{~min}$. and milk plasma was stored in a polyethylene tube at $-20^{\circ} \mathrm{C}$ until assayed.

Each milk plasma sample of $500 \mu$ l was pipetted into a test tube and $4 \mathrm{ml}$ of diethyl-ether was added. After mechanical shaking for $3 \mathrm{~min}$., further centrifugation at $3000 \mathrm{rpm}$ for $10 \mathrm{~min}$. was done and the supernatant was placed into an other test tube. This process was repeated twice and the solvent extracts were obtained. The extracts were then washed with $1 \mathrm{ml}$ of distilled water and subjected to mechanical shaking for $2 \mathrm{~min}$. After shaking, they were centrifuged at $3000 \mathrm{rpm}$ for $10 \mathrm{~min}$. The supernatant, placed in a test tube, was immersed in a waterbath $\left(37^{\circ}-38^{\circ} \mathrm{C}\right)$ and a continuous flow of nitrogen evaporated the sample to dryness. Dried residue was dissolved in $100 \mu \mathrm{l}$ of benzene : methanol $(85: 15 \mathrm{v} / \mathrm{v})$ solvent twice before it was separated by the Sephadex LH-20 gel column chromatography. Three fractions of estrogens obtained from the purification methods described 


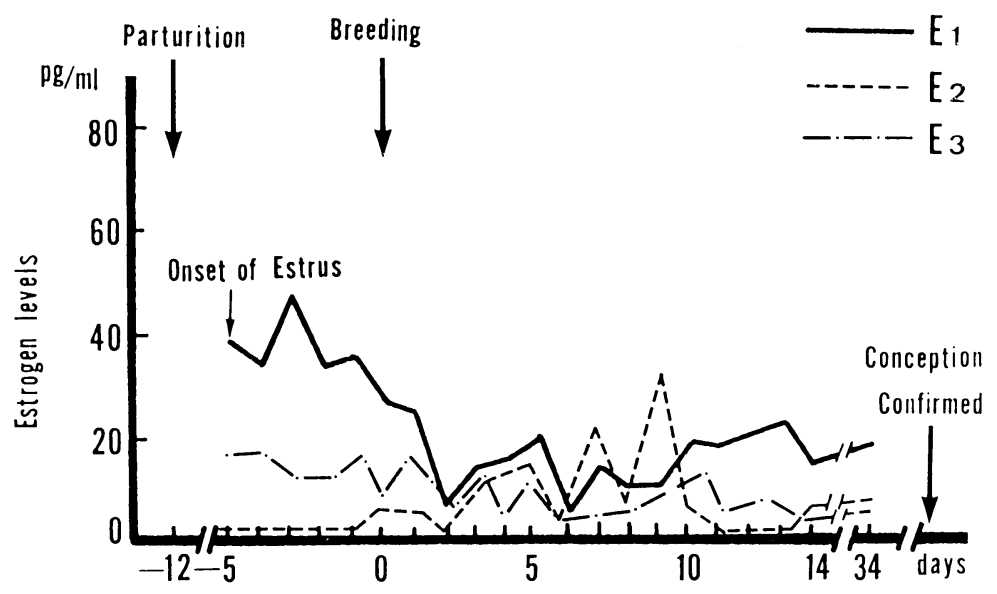

Fig. 1. Changes of estrone, estradiol-17 $\beta$ and estriol concentration in milk of mare case 1 during foal estrus.

above were measured by the Dextran-Charcoal method of radioimmunoassay (RIA) according to Makino (1972).

Antisera against E1-, E2- and E3-6-CMO-BSA were purchased from the Teikoku Hormone Manufacturing Co. (Tokyo Japan). The Crossreactions of $\mathrm{E} 1$ antisera with $\mathrm{E} 2$ and $\mathrm{E} 3$ were $2 \%$ and $1.6 \%$. Cross-reactions of $\mathrm{E} 2$ antisera with E1 and E2 were $3 \%$ and $2 \%$. These of E3 antisera with E1 and E2 were $0.01 \%$ and $0.5 \%$, respectively. The coefficient of variations for intra- and inter-assays was $10 \%$ and $16 \%$ for E1 : $15 \%$ and $19 \%$ for $\mathrm{E} 2$ : $12 \%$ and $18 \%$ for E3, respectively.

\section{Results}

The variations of concentration in three estrogens in milk daily obtained from each mare were presented in Figs. 1 5.

Case 1: The mare showed the onset of foal heat on day 7 postpartum and she was bred on day 5 of the foal heat and conceived on that mating. E1 concentration in milk maintained more than $30 \mathrm{pg} / \mathrm{ml}$ for 5 days from the onset of estrus ( 5 days before breeding). A peak of $50 \mathrm{pg} / \mathrm{ml}$ was seen on day 2 of the estrus (3 days before breeding) and then the level of E1 declined with time. On day 7 of the estrus (day 1 after breeding), E1 level was less than $20 \mathrm{pg} / \mathrm{ml}$. During the foal estrus, E2 level was less than $10 \mathrm{pg} / \mathrm{ml}$ without significant changes. On day 7 after breeding it increased to $22.5 \mathrm{pg} / \mathrm{ml}$. On day 9 after breeding, it showed a peak of 32.5 $\mathrm{pg} / \mathrm{ml}$, and thereafter it declined with time. E3 level never exceeded $20 \mathrm{pg} / \mathrm{ml}$ before and after breeding (Fig. 1).

Case 2: The mare showed the onset of estrus on day 14 postpartum. She was bred on day 6 of the foal estrus and conceived on that mating. E1 level showed more than $60 \mathrm{pg} / \mathrm{ml}$ for 2 days (3 days before breeding), then it declined to $40 \mathrm{pg} / \mathrm{ml}$ on day 5 of the estrus (on breeding day). After the breeding, the level maintained less than $30 \mathrm{pg} / \mathrm{ml}$. E2 level during estrus fluctuated between $20 \mathrm{pg} / \mathrm{ml}$ and $40 \mathrm{pg} / \mathrm{ml}$. Thereafter, it subsequently increased and decreased with 1 or 2 days interval. E3 level never exceeded $15 \mathrm{pg} / \mathrm{ml}$ throughout the experiment (Fig. 2).

Case 3: The mare showed the onset of estrus on day 2 postpartum ( 8 days before breeding). This mare did not conceive on the first breeding on day 8 of the foal estrus. The second estrus come on 14 days after the first breeding. She was mated again on day 21 after the first breeding and conceived on the second breeding. E1 level remained less than $20 \mathrm{pg} / \mathrm{ml}$ during the first estrus. However, 7 days before the second estrus, it increased to $40.9 \mathrm{pg} / \mathrm{ml}$ and maintained at this level throughout the 7 days. E2 level was $28.5 \mathrm{pg} / \mathrm{ml}$ on day of the onset of foal estrus, subsequently declining with time. It was 17.7 $\mathrm{pg} / \mathrm{ml}$ on the final day of estrus. E3 level was less than $10 \mathrm{pg} / \mathrm{ml}$ throughout the first and sec- 


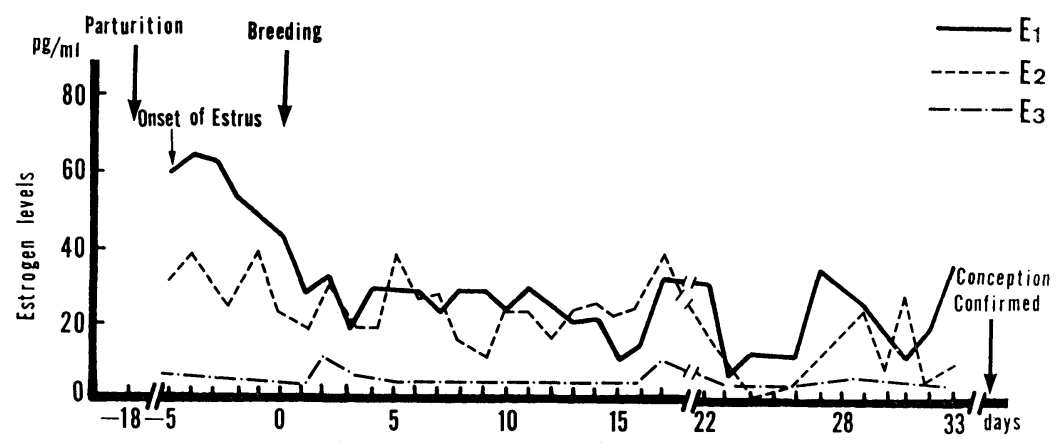

Fig. 2. Changes of estrone, estradiol-17 $\beta$ and estriol concentration in milk of mare case 2 during foal estrus.

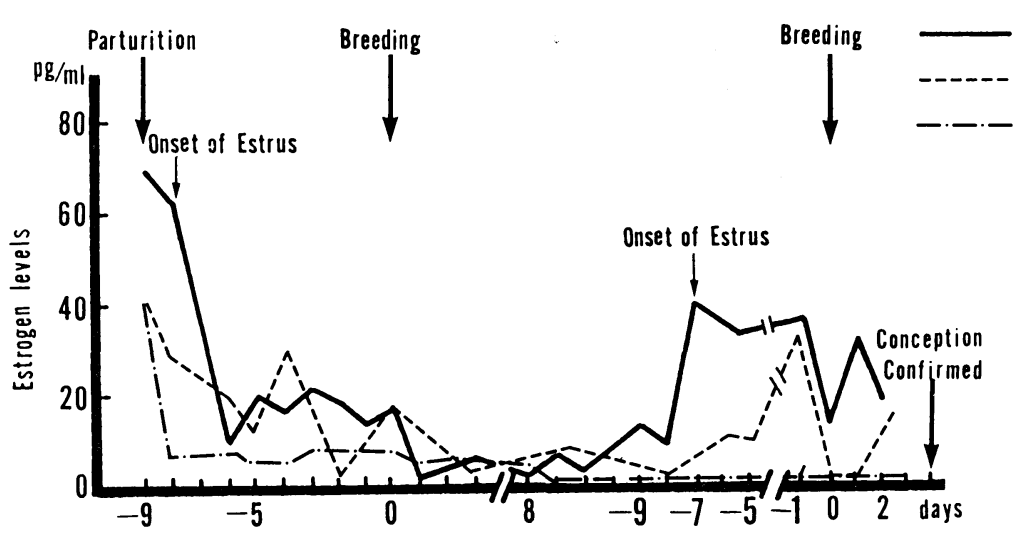

Fig. 3. Changes of estrone, estradiol-17 $\beta$ and estriol concentration in milk of mare case 3 during foal estrus.

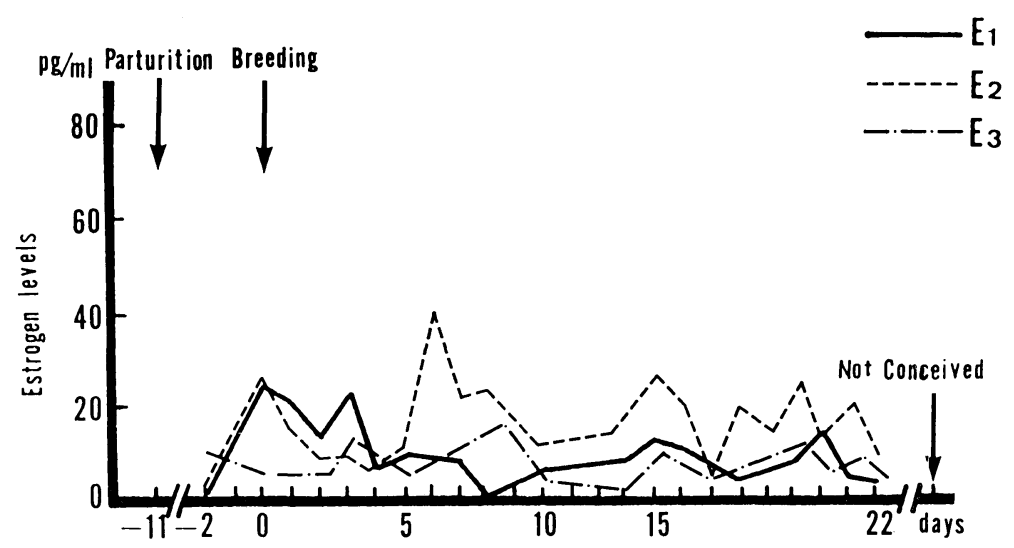

Fig.4. Changes of estrone, estradiol-17 $\beta$ and estriol concentration in milk of mare case 4 during foal estrus. 
ond estrus (Fig. 3).

Case 4: The mare was bred on day 11 postpartum, but she failed to conceive. E1 level was low, approximately $20 \mathrm{pg} / \mathrm{ml}$ or less during the foal estrus. After breeding, it maintained at $20 \mathrm{pg} / \mathrm{ml}$ for 4 days, and decreased to less than $10 \mathrm{pg} / \mathrm{ml}$ throughout the experiment. E2 level was $26.6 \mathrm{pg} / \mathrm{ml}$ on the breeding day and then it decreased with time. Six days after breeding it increased again to $42 \mathrm{pg} / \mathrm{ml}$. Thereafter, it subsequently increased and decreased. E3 level fluctuated between $5 \mathrm{pg} / \mathrm{ml}$ and $10 \mathrm{pg} / \mathrm{ml}$ throughout the experiment (Fig. 4).

Case 5: The first estrus commenced on day 9 postpartum, but breeding was skipped because of detection of two mature follicles by rectal palpation. E1 level was higher than $30 \mathrm{pg} / \mathrm{ml}$ for 3 days before the onset of estrus, subsequently it decreased. During estrus, it increased again to $40 \mathrm{pg} / \mathrm{ml}$ for 3 days and subsequently declined.

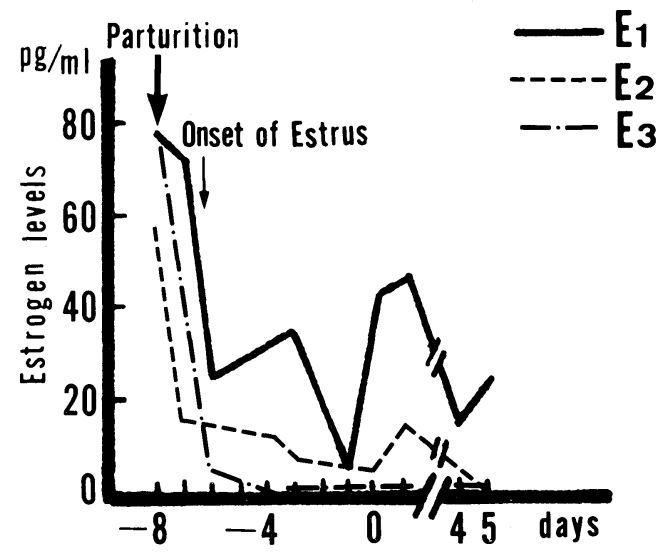

Fig. 5. Changes of estrone, estradiol-17 $\beta$ and estriol concentration in milk of mare case 5 during foal estrus.

E2 level was $15.8 \mathrm{pg} / \mathrm{ml}$ on day 2 and decreased to less than $1 \mathrm{pg} / \mathrm{ml}$ on day 5 of the estrus, without any increase again thereafter. E3 level decreased to $5.1 \mathrm{pg} / \mathrm{ml}$ on day 2 postpartum, remaining to be low thereafter (Fig. 5).

\section{Discussion}

The length of estrous period of the mare averages 7 days and ovulation occurs one and half days before termination of estrus (Sato and Hoshi, 1939). Further, the optimum breeding time is penultimate to ovulation day, totaling 3 days.

There are few reports on sexual steroids in milk of the mare during estrus. Estradiol level in jugular peripheral blood plasma peaks at $62 \pm 26$ (mean $\pm \mathrm{SE}$ ) $\mathrm{pg} / \mathrm{ml}$ on the onset of foal estrus and decreases to $21 \pm 5.3 \mathrm{pg} / \mathrm{ml}$ on ovulation (Norden et al., 1978). On the other hand, estradiol increases to a peak in mongrel mares, 1 to 3 days before ovulation (Pattison et al., 1972). Furthermore, the progesterone levels in blood and milk during the foal heat of Quarter Horse mares averaged less than $2 \mathrm{ng} / \mathrm{ml}$ in milk and $1 \mathrm{ng} / \mathrm{ml}$ in blood plasma (Gunter et al., 1980).

In the present study, only fluctuation of E1 concentration in milk showed a close relation to the estrous cycle in 5 Thoroughbred mares. No relevant and significant levels during the estrous cycle were obtained on E2 and E3 concentration in the milk. Therefore, it may be possible to assume that these two estrogenes, E2 and E3, have no relevant importance in predicting capability of conception at estrus of mares.

Mares of case 1 and 2 conceived on the first breeding in foal estrus. Estrone concentrations in milk of these mares during foal estrus were over $40 \mathrm{pg} / \mathrm{ml}$ and maintained over $30 \mathrm{pg} / \mathrm{ml}$ during the following 5 days after the onset of estrus. A mare of case 3 did not conceive on the first breeding during foal estrus but she conceived on the second breeding of the subsequent estrus. The peak concentration of $\mathrm{El}$ in milk during foal estrus was more than $60 \mathrm{pg} / \mathrm{ml}$ and maintained over $30 \mathrm{pg} / \mathrm{ml}$ during the following 3 days, but in the second estrus a peak of over $40 \mathrm{pg} / \mathrm{ml}$ was observed and maintained at this level for the following 7 days. As a result, conception occurred on the second breeding.

These results suggest that E1 concentration in milk is reliable in predicting capability of conception at foal estrus. It is assumed that a higher surge of El concentration in milk more than $30 \mathrm{pg} / \mathrm{ml}$ at least for 5 days, with a peak of over $40 \mathrm{pg} / \mathrm{ml}$, may be necessary for good conception, whereas in the case of lower E1 level during foal estrus conception will be unsuccessful.

One breeding (case 5 mare) was terminated in spite of its El concentration peaked more than $40 \mathrm{pg} / \mathrm{ml}$, because 2 follicles were detected by 
rectal examination. E1 surge length of this mare was short (only 3 days).

Multiple ovulation was observed in $38 \%$ of mares during a estrous period (Arthur, 1958; Osborne, 1966). Furthermore, other authors (Jeffcot and Whitwell, 1973; Platt, 1973) recommend that breeding should be skipped when more than 2 mature follicles are detected in the ovary during estrus, because $65 \%$ of multiple pregnancies in the mare would abort or undergo immature delivery.

It is difficult to define the optimum breeding period of mares in foal estrus, because the estrous length is short and the cycle is irregular. Today, detection of estrus in mares still relies on testing by the stallion and rectal examination. Furthermore, these methods do not assure the estrus detected to be conceivable.

This is probably the first report that deals with El concentration in milk during the estrus and the measurement of E1 may give a good guide to know the estrus to be capable of conception.

\section{References}

Arther GH (1958) An analysis of reproductive func- tion of mares based on postmortum examination. Vet Rec 70: 682-686.

Gunter JD, Forley CW, Gaveric HA, et al. (1980) Comparison of milk and blood plasma progesterone concentrations in cycling and pregnant mares. J Anim Sci 51: 1131-1138.

Jeffcot LB, Whitwell KT (1973) Twinning as a cause of foetal and neonatal loss in the Thoroughbred mare. J Comp Path 83: 91-106.

Makino $T$ (1972) Radioimmunoassay of plasma sex steroids. Folia Endocrinol Japonica 49: 629-645 (in Japanese).

Norden PA, Oxender WD, Hafs HD (1978) Plasma luteinizing hormone, progestogenes, and estrogens in mares during gestation, parturition, and first postpartum estrus (focal estrus). Am J Vet Res 39: 1964-1967.

Osborne VE (1966) An analysis of the pattern of ovulation as it occurs in the annual reproductive cycle of the mare in Australia. Aust Vet $J$ 42: 149-154.

Pattison ML, Chen CL, Kelley ST, et al. (1974) Luteinizing hormone and estradiol in peripheral blood of mares during estrous cycle. Biol Reprod 11: 245-250.

Platt H (1973) Etiological Aspects of Abortion in the Thoroughbred Mare. J Comp Pathol 83: 199-205.

Sato S, Hoshi S (1939) Study on the reproduction in mares. V. Special reference to mating. Jpn $J$ Vet Sci 1: 512-514 (in Japanese).

\title{
分婏後初回発情期のサラブレッド雌馬の乳汁中ェストロジェンの变化
}

\author{
東野 利忠・清水 敬介 ・津曲 茂久 ・武石 昌敬 \\ 日本大学農獣医学部獣医臨床繁殖学研究室, 252 神奈川県藤沢市亀井野 1866
}

\footnotetext{
分婉後初回発情期のサラブレッド雌馬 5 頭より乳汁を オールの推移はその発情に抢ける受顺の叮能性:を予测す 採敢し，乳汁中のエストロン，エストラジオール $17 \beta$ 打 るための指標として適切でなかったが，エストロンはそ 上びエストリオールの 3 分画を RIA 法で測定した。 の指標となりらる可能性が示唆された。
}

初问発情期の乳汁中エストラジオール $17 \beta$ とエストリ 